\title{
Economic Regulation of Intrastate Air Carriers in California
}

\author{
Marvel M.Taylor*
}

P ECENT DEVELOPMENTS in economic regulation of intrastate airline 1 operations have emphasized the long-existing need for Congressional review of the inter-relation of federal and state economic jurisdiction over air carriers and for clarification of certain California constitutional and statutory provisions relating to Public Utilities Commission jurisdiction. Because of unique geographic and economic factors, commercial intrastate air travel has developed faster and with greater economic significance in California than in any other state. Attendant legal questions have arisen out of the uncertainty regarding the extent of exclusive federal control as well as from the application to those activities which are not subject to exclusive federal jurisdiction of certain state constitutional provisions, adopted while the airplane was still a combination box-kite and windmill not imagined as a means of mass transportation.

Future developments in California may well lead the way towards settling the problems of federal, state and local regulation of air travel throughout the nation. The unlimited potential of air travel and its rapid development in recent years shows the need for resolution of the jurisdictional issues created by present laws and decisions, and for the development of a far-sighted and sympathetic governmental attitude to realize this potential. A comparable opportunity to further the development of intrastate and local-service air transportation may never again arise if the present solution of these problems is not forthright and effective.

Congress and the states have not yet produced a sound regulatory pattern. Air carriers, serving many masters, face a nearly impenetrable mass of confusion, duplication and uncertainty in economic regulation. This complexity of regulation has an important adverse affect on the development of an air transportation system which will serve national, sectional and local needs adequately. This fact requires the resolution of existing jurisdictional conflicts and the establishment of a flexible regulatory framework aimed at maximun social utilization of the inherent advantages of the airplane. The framework should be tight enough to protect the public interest in safety, service and competition, and loose enough to permit the still unrealized potential of air transportation to develop as rapidly as eco-

* Member, San Francisco Bar. 
nomic and engineering factors permit. In perhaps no other area has government regulation developed as rapidly in recent months as in air transportation, and certainly none presents a more acute problem from the standpoint of the industry involved.

\section{ECONOMICS AND GEOGRAPEY}

The characteristics of commercial air travel have in the past been such that only long flights with high space utilization were profitable, ${ }^{1}$ but the post World War II developments have increased the productivity of shorter hanls to the point where local service air lines and inter-urban helicopter services are an actuality. California is so ideally suited for the operation. of a large scale intrastate air transportation system that the Los AngelesSan Francisco route is the most heavily traveled commercial air route in the nation. ${ }^{2}$ Only Pennsylvania and New York have equally large population centers at distances comparable both in miles and in hours of travel time required by existing surface transportation systems. Both these states, however, have distinguishing economic, geographic and sociological factors, so that intrastate air transportation systems comparable to Califorma's have not developed. ${ }^{3}$ Other states with comparable distances do not (1946)

1 Barnes, The Economic Role of Air Transportation, 11 LAw \& Contenrp. Prob. 431, 439

2 Air Force, Vol. 36, No. 8, August 1953, p. 20. The CAA reports that the largest volume of airline travel is on the 340-mile trip between Los Angeles and San Francisco-more than 36,000 passengers per month. The next busiest air lane is between New York and Miami. Other pairs of cities with more than 1,000 passengers flying between them every day are New York. and Chicago, New York and Boston, and New York and Washington.

3 Philadelphia, with a population of 3,660,676, is 255 air miles from Pittsburgh, which has a population of $2,205,544$. All other Pennsylvania cities have populations of less than one-half million by the 1950 census. Pennsylvania is distinguishable from California in that the surface transportation facilities are more extensively developed, the distance is significantly less, the population trend of Pennsylvania is downward, and the common carrier schedules between the intrastate mail-hine points benefit fron extremely high density imterstate schedules. Of great significance is the fact that Pittsburgh and Philadelphia belong to different economic regions.

New York has two major population centers located at opposite ends of the state; also upstate are two cities with populations near the one-half million mark. Sizes and distances are:

$\begin{array}{lccc} & \text { New York City } & \text { Buffalo } & \text { Albany } \\ \text { New York City }(12,831,914) & \ldots \ldots . & 290 & 140 \\ \text { Buffalo }(1,085,606) & 290 & \ldots \ldots . & 255 \\ \text { Albany }(512,527) & 140 & 255 & \ldots . \\ \text { Rochester }(484,877) & 255 & 55 & 195\end{array}$

In many respects California and New York are similar. The major distinctions are the better developed surface transportation system, the disparity of population center sizes, somewhat shorter distances, and far greater trunk-line interstate rail service upon the Buffalo-New Yori City route than upon the San Francisco-Los Angeles run. There is a federally certificated local service air carrier serving the smaller New York comnrunities, but there is not the substantial intrastate air travel systenı developed in New York that exists in California, based upon carriers operating outside the economic regulations of the Civil Aeronautics Act of 1938. 
have the population centers; states with population centers do not have the distances. ${ }^{4}$

Califorma contains two of the fourteen metropolitan areas of the nation with populations of over one million persons. ${ }^{5}$ According to the 1950 Census, the Los Angeles Metropolitan Area is the third largest, containing 4,339,225 residents. The San Francisco-Oakland area, with 2,214,249, ranks seventh. The San Diego area is twenty-ninth nationally, having 535,967 persons.

Depending upon the type and style of transportation desired, a traveler between the two major Califorma cities is, at his choice of services available, either a commuter or a vacationist. Over the 340 air miles of the route, the comparative schedules and fares are:

\begin{tabular}{|c|c|c|c|c|}
\hline \multirow{2}{*}{ Coach } & $\mathbf{R}$ & \multicolumn{2}{|c|}{ RAII } & \multirow{2}{*}{ Bus } \\
\hline & Standard & Coach & Puillman & \\
\hline .........\$15.53 & $\$ 25.36$ & $\$ 10.93$ & $\$ 26.91$ & $\$ 6.8$ \\
\hline ents/mile _.... $41 / 2$ & $72 / 5$ & $31 / 5$ & $7 \%$ & 2 \\
\hline Travel hours .... 13/4 & $12 / 3$ & $101 / 3$ & $103 / 4$ & 10 \\
\hline Miles/hour .......195 & 205 & 33 & 33 & 34 \\
\hline
\end{tabular}

4 Florida and Texas have comparable distances. Respective populations and distances are:

\begin{tabular}{|c|c|c|c|c|c|}
\hline \multirow{2}{*}{\multicolumn{2}{|c|}{$\begin{array}{l}\text { Florida } \\
\text { Miami }(488,689)\end{array}$}} & Miami & \multicolumn{2}{|c|}{ Tampa } & Jacksonville \\
\hline & & $\ldots . . .$. & & 10 & 320 \\
\hline Tampa $(406,175)$ & & 210 & & $\ldots .$. & 180 \\
\hline Jacksonville $(302,711)$ & & 320 & & 180 & $\ldots . . .$. \\
\hline Texas & Houston & Dallas & Ft. Worth & San Antonio & El Paso \\
\hline Houston $(802,102)$ & ...... & 245 & 250 & 230 & 680 \\
\hline Dallas $(610,852)$ & 245 & ...... & 45 & 270 & 575 \\
\hline Ft. Worth $(359,246)$ & 250 & 45 & ....... & 260 & 530 \\
\hline San Antonio $(496,090)$ & 230 & 270 & 260 & $\ldots . .$. & 495 \\
\hline El Paso $(197,934)$ & 680 & 575 & 530 . & 495 & ....... \\
\hline
\end{tabular}

Note that only two cities have populations exceeding one-half million, contrary to popular superstition.

Michigan and Illinois have large population centers at one location and no comparable centers elsewhere in the states.

Michigan

Detroit $(2,973,019)$

Grand Rapids $(287,020)$

Flint $(270,034)$

\begin{tabular}{rcc} 
Detroit & Grand Rapids & Flint \\
\hdashline... & 140 & 55 \\
140 & $\ldots \ldots .$. & 100 \\
55 & 100 & $\ldots \ldots .$.
\end{tabular}

Illinois-Chicago $(5,475,535)$ is 125 air miles from the next largest city in Illinois, Peoria $(249,918)$.

Missouri and Ohio have two or more major population centers. Respective populations and distances are:

Missouri-Kansas City $(808,231)$ is 225 air miles from St. Louis $(1,673,467)$. All other city areas are under one-half million.

$\begin{array}{lcccc}\text { Ohio } & \text { Cleveland } & \text { Cincinnati } & \text { Youngstown } & \text { Columbus } \\ \text { Cleveland }(1,457,601) & \ldots \ldots . . & 215 & 65 & 125 \\ \text { Cincinnati }(898,031) & 215 & \ldots \ldots . . & 245 & 105 \\ \text { Youngstown }(526,599) & 65 & 245 & \ldots \ldots . & 140 \\ \text { Columbus }(501,882) & 125 & 105 & 140 & \ldots . . .\end{array}$

- Other California metropolitan areas with populations over one-quarter million are: San Jose, 288,928; San Bernardino, 280,252 ; Sacramento, 275,659; Fresno, 274,225. 
The significance of this comparison is that for twice the lowest existing fare of any type of carrier, the bus, a person may make the same trip by air coach and enjoy a full eight-hour day at his destination, rather than in travel. Further, the prospects of a $2 \dot{\phi}$ per mile air coach fare may be in the offing. Such a fare would enable air carriers to compete with bus and rail carriers on a price basis. With development of more efficient jet and turboprop airplane engines, even faster schedules will be feasible. Already one air carrier is experimenting with a one hour and twenty minute schedule. ${ }^{6}$

The trend of passenger distribution between different types of carriers reflects the relative advantages of air coach travel. In the first year of air coach operations, the number of air passengers jumped sixty per cent over the preceding year, and more persons traveled by air than by any other form of commercial transportation. ${ }^{7}$ One air coach operator with an average load factor of $83.7 \%^{8}$ considers its sources of traffic to be: ${ }^{9}$

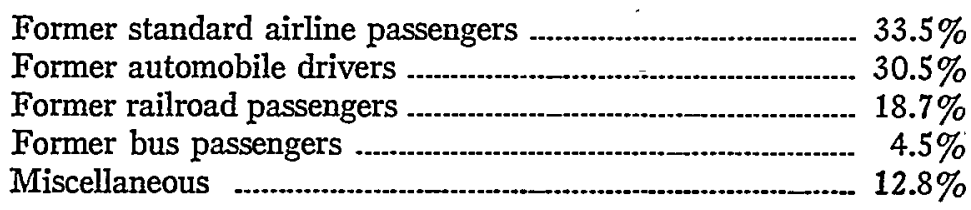

Although reports vary as to the source of the shift to air coach travel, all agree that a significant portion represents the tapping of a new commercial transportation market. The California Public Utilities Commission has estimated that $41 \%$ of the air coach passengers are "people who otherwise would either not have traveled or would have used private transportation facilities." 10 Air coach service on this route has grown so that of the 38 daily round trips now flown by all scheduled carriers, 17 are made by air coaches. On week-ends the 43 scheduled round trips include 24 air coach schedules. Recent reports show a continually increasing number of air coach passengers between Los Angeles and San Francisco. ${ }^{11}$

EVENTS LEADING TO THE CURRENT SERIES OF DECISIONS

Prior to 1949, all airlines operating regularly-scheduled flights between California localities operated under federal certification pursuant to the Civil Aeronautics Act of 1938. On January 2 of that year California Central Airlines, without certification under the economic regulations of the Act, commenced air coach operations between San Francisco and Los Angeles, charging a $\$ 9.99$ one-way fare-less than one-half the fare charged

${ }^{6}$ Aviation Week, Vol. 55, No. 6, Aug. 6, 1951, p. 51.

749 Cal. PUC 494,496, March 14, 1950, Decision 43932. Later statistics are not available.

8 Aviation Week, Vol. 55, No. 6, Aug. 6, 1951, p. 52.

${ }^{0}$ California Central Airlines, reported in Aviation Week, Vol. 54, No. 3, Jan. 15, 1951, p. 60.

10 Supra note 7.

11 Supra note 2. 
by the federally certificated carriers on the route. The intense competition for the existing market and the creation of a new air travel market forced United Air Lines and Western Air Lines, the federally certificated carriers, to shift part of their deluxe style schedules to the more austere air coaches. The air coach makes possible lower fares, due to higher-density seating arrangements-more seats in the same airliner. A fourth carrier, Pacific Southwest Airlines, entered the competition as a non-federally-certificated intrastate airline similar to Cal-Central. Soon thereafter a Public Utilities Commission investigation into the coach fares was commenced, and resulted in a decision that the fares then being charged were reasonable under state law. ${ }^{12}$ Counsel for Cal-Central in this proceeding raised objections to PUC jurisdiction over air carriers. The issue was dismissed with only a footnote comment by the Commission. ${ }^{13}$

In February 1951, the Civil Aeronautics Board "urged" carriers flying air coaches between Los Angeles and San Francisco to raise their fares

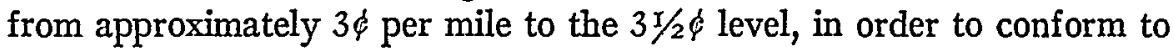
the national air coach fare pattern. ${ }^{14}$ Cal-Central, United and Western complied with the "suggestion" on March 1, after informing PUC they were so acting. Pacific Southwest followed a different procedure, and first requested PUC approval of the higher fare, which was granted, effective March 29. Meanwhile, PUC had commenced an investigatory proceeding upon its own motion. On April 5, the California Attorney General rendered an opimion that PUC had authority to determine rates and charges for intrastate airlines. ${ }^{15}$ The PUC determination, in what has become known as the Cal-Central decision, followed on April 24, 1951, and authorized the higher fare of $\$ 11.70$, effective May 9, for Cal-Central, United and Western, and ordered rebates to be paid "wherever possible" to passengers who paid the higher fare from March 1 through May $8 .{ }^{16}$

In this decision, the PUC took the position that it may act directly, under Sections 20 and 22, Article XII, of the California Constitution, to regulate rates and charges of air carriers operating between points within the state; that it needs no statutory authorization from the legislature to so act; and, that it has jurisdiction over commercial air travel wholly within the state, to the exclusion of the Civil Aeronautics Board, even where carriage of mail is involved. United and Western petitioned the state supreme

12 Supra note 7.

13 Footnote 2 of Dec. 43932, supra note 9, reads: “. . . Under the Constitutional provisions . . . the Commission's powers are sufficient for procedings of this kind."

14 Aviation Week, Vol. 54, No. 7, Feb. 12, 1951, p. 41.

15 Opinion No. 51/47 (April 5, 1951) 17 Ops. Cal. Att'y Gen. 140. This opinion ignores all federal aspects of the question. For a general comment on the value of Attorney Gencral's opinion see Jackson, J., in McGrath v. Kristensen, 340 U.S. 162, 176 (1950).

16 Decision 45624, 50 Cal. PUC 563 (1951). 
court for review. It was denied without opinion. ${ }^{17}$ The petition was then carried to the Supreme Court of the United States based upon the conflict of federal and state regulation, but the appeal was dismissed for lack of a "substantial" federal question. ${ }^{18}$

The events represent the first judicial consideration of state economic jurisdiction over wholly intrastate airlines, and the first time the scope of federal and state regulatory jurisdiction under the Civil Aeronautics Act has been taken to the highest court in the nation. The United and Western petitions to the Supreme Court of the United States are significant in that both carriers are subject to regulation by the Civil Aeronautics Board for their intrastate routes as well as interstate routes. Mail is carried upon the intra-California routes by Umited and Western, and compensation is granted under the provisions of the Civil Aeronautics Act, authorizing subsidies to carriers, which, together with the rate-fixing powers of the Civil Aeronautics Board, are the heart of the economic regulations.

Whether the United States Supreme Court agreed with the PUC and its interpretation of state powers under the Civil Aeronautics Act certainly cannot be determined. The only issue then before that court was whether the appeal should be dismissed with respect to the rebate order. In holding that the order, which by its own terms was to be followed only "wherever possible," did not present a "substantial" federal question, the Supreme Court exercised jurisdictional discretion, and nothing more. Nevertheless, in spite of the fact that it has been repeatedly stated that denial of review is not to be construed as an opmion on the merits, the action does strengthen the hands of states that seek to impose economic regulation upon the noncertified air carriers.

Western Air Lines later asked the Civil Aeronautics Board to rule whether it should comply with the PUC rebate order. ${ }^{19}$ It had previously asked the $\mathrm{CAB}$ counsel for advice in this regard, but received no answer. ${ }^{20}$ Western's position was that compliance would be a violation of the Civil Aeronautics Act prohibition on rebates. Reportedly, CAB informally suggested that Western ask for an exemption from the Act under the circunstances. ${ }^{21}$ On September 1, 1952, at long last, United offered to make the ordered rebates, with Western soon after following suit.

After the courts refused to prohibit the PUC from imposing its jurisdiction over the carriers, the Commission sought penalties for ignoring the provisions of its rebate order. Penalties of $\$ 138,000$ were sought from each carrier $-\$ 2,000$ per day for 69 days. When the Commission went to court

\footnotetext{
1737 A.C. No. 18, Minutes, pp. 1-2, SF 18426, SF 18427.

18 United Air Lines, Inc. v. PUC, 342 U.S. 908 (1952).

10 Aviation Week, Vol. 56, No. 20, May 19, 1952, p .91.

20 Ibid.

21. Ibid.
} 
in the name of the people of the state, it lost the first two rounds as demurrers to its complaints were sustained in two departments of the District Court of Appeals in June of this year. ${ }^{22}$ The intermediate appellate courts both ruled in favor of the carriers upon the ground that the PUC lacked power, either directly under Sections 20 and 22 of Article XII, or under Section 2107 of the Public Utility Code, to levy such penalties. Both interpreted the constitutional and statutory provisions as not applying to transportation companies which were not within the contemplation of the legislature when the constitutional and statutory provisions involved were adopted, even though the wording of both sets of provisions is broad enough to cover air carriers if the courts choose to so interpret the sections. Review has been granted by the State Supreme Court so that a full consideration of the state constitutional law is in the making at this time.

On June 15, 1952, Cal-Central petitioned the PUC for a fare increase to $\$ 13.50$, and also demanded that Western and United be forced to raise their coach fares. ${ }^{23}$ Thus, the positions were reversed, in that the original rate-cutter was boosting fares and a state agency, rather than the federal one, was serving as the regulatory body.

A wholly different proceeding involving the same issue of jurisdiction resulted in a decision rendered on December $3,1952,{ }^{24}$ when a three-judge Federal District Court held that the $\mathrm{CAB}$ and not the PUC had jurisdiction over air carriers flying between Long Beach, Califorma, and Avalon, California, located on the Channel Island of Santa Catalina, some thirty miles off-shore, and enjoined the PUC from "interfering with such paramount jurisdiction." The decision was very carefully rested upon the Civil Aeronautics Act definition of "air transportation" to include "the carriage by aircraft of persons or property ... between places in the same state of the United States through the airspace over any place outside thereof." The court found "that a substantial portion of these 30 miles lies over the high seas and is not within the State of Califorma. Hence, it follows that air transportation through the air space thereover is over a place outside of the State of California." 25 The broader contentions of the parties as to conflicting areas of jurisdiction were studiously avoided, but the need for speedy resolution of the jurisdictional question was clearly shown. The PUC has appealed to the U. S. Supreme Court, and the opportunity for a

22 People v. United Air Lines, Inc., 118 A.C.A. 454, 258 P.2d 66 (1953) ; People v. California Central Airlines, 118 A.C.A. 683, 258 P.2d 577 (1953); People v. Western Airlines Inc., 118 A.C.A. 689,258 P.2d 581 (1953).

23 Cal. PUC Resolution 1093-A; California Central Airlines v. United Airlines and Western Air Lines, Cal. PUC Case 5397, filed July 22, 1952.

24 United Air Lines v. PUC, 109 Fed. Supp. 13 (S.D. Cal. 1952).

$25 I d$. at 16. 
clear judicial definition of respective powers of various governmental bodies is again at hand.

The judicial results to date show the excessive burden thrust upon the carriers in their attempt to bring progress to the traveling public. It is submitted that the carriers are entitled to know the law to which they are subject. At present, no lawyer can answer that question with assurance. Regardless of how the present litigation develops, until the jurisdictional deinarcation is sharply drawn new economic and technological developments will present new legal problems to legal machinery ill-equipped to handle them. The problem is essentially legislative, and until approached upon that basis the courts can, at best, act in shadows, hoping to reach the right result in the particular case and avoid creating a precedent that will not serve the best interest of the public and the parties in the next round of the struggle. To date, the courts have compounded uncertainly with evasion, ambiguity and confusion. The opportunity is now at hand for a comprehensive judicial review of both state and federal law by the highest courts. If the opportunity is not seized and acted upon in terms of economic reality, further developinent of air travel can be stifled so that the public will pay higher prices for inferior service by subsidized carriers.

\section{PROBLEMS OF FEDERAI LAW}

The relative areas in which the federal, state and local governnients can regulate different phases of civil aviation under the Civil Aeronautics Act of 1938 have been frequently and well discussed. ${ }^{26}$ Those who have attempted to define precisely the limits of respective jurisdictions have either failed entirely, or have described only the respective areas in which regulatory action has occurred. The more realistic have frankly recognized the problem as a dynamic one regarding which no precise delineation could be made.

In other fields, where a federal statute has not been unequivocally specific, the Supreme Court has treated the problen of concurrent state regulation as one of balancing local interests against the interference with federal regulation. ${ }^{2 \pi}$ State legislative or adnimistrative action is valid, unless

20 Ballard, Federal Regulation of Aviation, 60 Harv. L. Rev. 1235 (1947) ; Binzer, Civil Aviation-The Relative Scope of Jurisdiction of the State and Federal Government, $33 \mathrm{Kr}$. L.J. 276 (1945); Green, The War Against the States in Aviation-Battle for Exclusive Federal Control, 31 VA. L. Rev. 835 (1945); Rhyne, Federal, State and Local Jurisdiction over Civil Aviation, 11 Law \& Contemp. Рвов. 459 (1946); Hamley, Appropritate Areas of State Economic Regulation, 11 Law \& ConteMr. ProB. 488 (1945).

27 Southern Pacific Co. v. Arizona, 325 U.S. 761 (1945) ; City Service Co. v. Peerless Co., 340 U.S. 179, 186 (1950), where Mr. Justice Clark states: "The Commerce Clause gives to Congress a power over interstate commerce which is both paramount and broad in scope. But due regard for state legislative function has long required that this power be treated as not exclusive .... It is now well settled that a state may regulate matters of local concern over 
found to discriminate against national interests protected by federal consituation or statute, ${ }^{28}$ or unless clearly contravened by federal legislation. ${ }^{29}$

Under the Civil Aeronautics Act of $1938,{ }^{30}$ the Federal Government purportedly has occupied the field of air safety regulation to the exclusion of the states. ${ }^{31}$ However, duplicating and supplemental state safety regulation is widespread. ${ }^{32}$ Under this Act, federal economic jurisdiction over commercial airlines conceivably may be as nearly total as federal safety jurisdiction, but has not been so extensively applied, because the Civil Aeronautics Board is uncertain regarding the scope of its economic powers. ${ }^{33}$ Legislation has been proposed to Congress which would remove some of the

which federal authority has not been exercised, even though the regulation has some impact on interstate commerce .... The only requirements consistently recognized have been that the regulation not discriminate agamst or place an embargo on interstate commerce, that it safeguard an obvious state interest, and that the local interest at stake outweigh whatever national interest there might be in the prevention of state restrictions. Nor should we lightly translate the quiescence of federal power into an affrmation that the national interest lies in complete freedom from regulation."

28 Panhandle Co. v. Michigan Comm., 341 U.S. 329 (1952); Dean Milk Co. v. Madison, 340 U.S. 349 (1951); Buck v. California, 343 U.S. 99 (1952).

29 Parker v. Brown, 317 U.S. 341 (1943); Hines v. Davidowitz, 312 U.S. 52 (1941); Allen Bradley-Local v. Board, 315 U.S. 740 (1942).

3052 Stat. 973 (1938), 49 U.S.C. c. 9 (1948).

31 Mr. Justice Jackson in Northwest Airlines v. Mimnesota, 322 U.S. 292, 303 (1944) states, "Congress has recognized the national responsibility for regulating air commerce. Federal control is intensive and exclusive. Planes do not wander about in the sky like vagrant clouds. They move only by federal permission, subject to federal inspection, in the hands of federally certified personnel and under an intricate system of federal commands ... its privi leges, rights and protection, so far as transit is concerned, it owes to the Federal Government alone and not to any state government." In C.A.B. v. Canadian Colonial Airlines, 41 F. Supp. 1006, 1009 (S.D.N.Y.1940), the Court said that the purpose of the Civil Aeronautics Act of 1938 was to secure the highest degree of federal control over safety. See also Fuxz, THE LAW op Aviation § 9 (3d ed. 1938); Rosenhan v. U.S., 131 F.2d 932 (1942); U.S. v. Drumm, 55 F. Supp. 151 (D. Nev. 1944).

39 Rathje, The Constitutionality of State and Mutricipal Air Traffic Control, 15 J. AIR L. \& Cosac. 108 (1948); Rhyne, Federal, State and Local Jutisdiction Over Civil Aviation, 11 Law \& Contemr. Prob. 459, 462, 467 (1946); McDonald and Kuhn, The Ocean Air-State or Federal Regulation, 31 VA. L. Rev. 363 (1945); Dykstra \& Dyxstra, Business Law of Avatron 25 (1946); Black, Uniformity in State Air Safety Regulation; Cooperative Federal. ism Applied, 15 J. AIR L. \& Comas. 181 (1948).

${ }^{33}$ It is the present position of the $C A B$ that wholly intrastate air carriers operating in California "are subject to the jurisdiction of the Board in the field of safety regulation. They are not subject to the economic jurisdiction of the Board so long as they confine their operations wholly to segments located within the boundaries of the State of California, and avoid serving any interstate traffic moving over these intrastate segments. They bave attempted to confine their operations in this manner and have managed for the most part to avoid the effects of economic regulation by the Board. As far as the Board's economic jurisdiction is concerned, it is not a question of the regularity or irregularity of the operations, but rather a question of whether the operations are confined to the purpose of serving purely imtrastate traffic." Letter of Emory T. Nunnelley, Jr., General Counsel, Civil Aeronautics Board, to this author, dated December 7, 1951. 
ambiguity and uncertainty of the present statute and help resolve the problem of federal-state powers. ${ }^{34}$

As yet, the federal government may not have gone as far in economic regulation as is constitutionally possible ${ }^{35}$ by clearly excluding the states. But state regulation has been haphazard, at best. ${ }^{36}$ Coinprehensive economic regulatory schemes have been established by states where a justifiable need is hard to find. ${ }^{37}$ Some states have provided economic regulation of intrastate air carriers by railroad or utilities commissions, while others have used independent aviation commissions. ${ }^{38}$ Only a small minority of states have omitted some type of regulation. ${ }^{39}$

As it applied to United and Western, the Cal-Central decision raised the problems of a state order requiring rebates in the face of a federal pro-

34 H.R. 1012, 78th Cong., 1st Sess. (1943) ; H.R. 3420, 78th Cong., 1st Sess. (1943) ; S. 246, 78th Cong., 1st Sess. (1943) ; H.R. 3383, 79th Cong., 1st Sess. (1945) ; H.R. 674, 79th Cong., 1st Sess. (1945) ; S. 1, 79th Cong., 1st Sess. (1945) ; H.R. 2337, 80th Cong., 1st Sess. (1947) ; Tipton, Legislative Program for Aviation, 11 LAw \& Contemp. ProB. 564 (1946); McCarran, Frontiers of Aviation Law, 14 J. AـR L. \& Comar. 344 (1947) ; Nunnelley, Federal Aviation Legislation: A Review of Some of the Basic Concepts Underlying Existing and Prospective Legislation, 14 J. AIR L. \& CoMar. 445 (1943); Proposed Amendments to the Civil Aeronautics Act of 1938, 1944 INs. L.J. 528; Faries, Major Problems of Civilian Aviation Law, 18 CaLIF. ST. B. J. 149 (1943) ; Hamley, Appropriate Areas of State Economic Regulation, 11 LAw \& CoNmearp. Prob. 488, 498 (1946). See also Baggett, Are Surface Carriers Grounded by Law?, 31 VA. L. REv. 337 (1945) ; Ryan, Economic Regulation of Air Commerce by the States, 31 VA. L. REv. 479 (1945) ; Neal, The Status of Non-Scheduled Operations Under the Civil Aeronautics Act of 1938, 11 Law \& Contemp. Prob. 508 (1946); Ryan, Problems of Our Domestic Air Transportation, 19 Notre Dame Law. 85 (1943); Taylor, A Practical Reconciliation of State and Federal Control, 12 J. ATR L. \& Comar. 232 (1941); Morris, State Control of Aeronautics, 11 J. ATR L. \& Comar. 320 (1940) ; Binzer, Civil Aviation-The Relative Scope of Jurisdiction of State and Federal Government, $33 \mathrm{~K}$.. L.J. 276 (1945); Jones and Davis, Air Coach Experiment and National Air Transport Policy, 17 J. AIR L. \& Comar. 1, 418 (1950); Landis, Air Routes Under the Civil Aeronautics Act, 15 J. AIR L. \& Comar. 295 (1948); Burt and Highsaw, Regulation of Rates in Air Tratsportation, 7 VA. L. Rev. 1, 378 (1946); Plaine, The Pattern of State Aviation Legislation, 15 J. ATR L. \& Conar. 58 (1948).

35 U.S. v. Wrightwood Dairy Co., 315 U.S. 110 (1942) ; Wickard v. Filburn, 317 U.S. 111 (1942); Cooley v. Board of Port Wardens, 12 Howe 299 (1851).

36 Rhyne, Federal, Siate and Local Jurisdiction over Civil Aviation, 11 LAw \& Contemp. Pros. 459 (1946) ; Armour, One Air Law or 49, 52 CaSe \& Conar. 48 (Oct. 1947); 89 Cong. REC. A1849 (1943) (Comments by Rep. Boren).

37 An example is the Nebraska State Railway Commission General Order No. 86, Supp. 1, reported 1951 U.S. Aviation Rep. 148. See also State ex rel. State Ry. Comm. v. Ramsey, 151 Neb. 333, 37 N.W.2d 502 (1949).

38 AIA. Code tit. 48 (1941), ALA. COde tit. 48 (Supp. 1950); ARK. Srar. tit. 74 (1947); Vr. Rev. Srar., tit. 22, c. 243 (1947); Ind. ANN. Star., tit. 14, c. 3 (Burns 1950 Replacement). The Indiana Aeronautic Commission, the agency authorized to provide economic regulation has declined to exercise its powers. See Ind. Aero. Comm. Proceedings, 16 J. AIR. L. \& Comar. 111 (1949). KY. Rev. Star. c. 183 (1942); N. M. Stat. ANN. c. 47 (1942); VA. Code, tit. 56, c. 7 (1950).

39 Georgia, Missouri and Nevada. Colorado formerly provided for economic regulation. See Coro. Srat. AnN. c. 17 (1936), Colo. Srat. ANN. c. 17 (Supp. 1949). See articles cited note 36 , supra. 
hibition ${ }^{40}$ and imposing a fare different from the one approved by the federal regulatory agency. ${ }^{41}$ With regard to fares, the order has the effect of shifting the cost-profit relationship upon particular routes so as to unbalance the cost-profit relationships as between different routes and the cost of air travel within different regions of the nation, and, by implication, permits the state regulatory agency to determine in some degree the need, size and effect of the federal subsidy. Also involved was approval of the state's view of its regulatory powers, which, if correct, may be applied much more extensively at a later date to the federally regulated air carriers, with far greater economic consequences. The problems are due to an obvious loophole in the federal statute permitting some carriers to operate free from federal regulation, a loophole which could easily be closed by judicial interpretation. ${ }^{42}$ These problems must ultimately be solved in some forum, judicial or legislative, at some time in the not far distant future. They cannot be side-stepped forever.

4049 U.S.C. $\$ 483$ (b) (1948).

4149 U.S.C. $\$ 483$ (a) (1948).

42 Compare 49 U.S.C. $\S 409(3)$ and $\S 409$ (10) (1948). The Civil Aeronautics Act follows the general regulatory pattern of the Motor Carriers Act of 1935. Many provisions were taken over substantially verbatim. Compare 49 U.S.C. § 1(18) with 49 U.S.C. § 481 (1948) (certificates of public convenience and necessity); 49 U.S.C. $\$ \S 6$ and 13 with 49 U.S.C. $\$ \S 484$ and 642 (1948) (rate making); 49 U.S.C. $\$ \S 6(6)$ and (7) (1948) with 49 U.S.C. $\$ 483$ (filing of tariffs). However, the Motor Carriers Act contains a section not duplicated in the Civil Aeronautics Act. 49 U.S.C. $\S 302$ (b) (1948) reads: "Nothing in this chapter shall be construed to affect the powers of taxation of the several States or to authorize a motor carrier to do an intrastate business on the highways of any State, or to interfere with the exclusive exercise by each State of the power of regulation of intrastate commerce by motor carriers on the high. ways thereof." Similar provisions are contained in 49 U.S.C. $\$ \S 303$ (b) (8), 304(a) (4a), 305(f), 306(a) and 316(e) (1948).

Other utilities witl similar provisions in applicable federal acts are telephone and telcgraph, Communications Act of 1934, 47 U.S.C. \$\$152(b), 153(e), 221(b) and 410(a) and (b) (1948) ; electrical power, Federal Power Act of 1935, 16 U.S.C. $\$ \S 824(\mathrm{a})$ and (b), $824 \mathrm{c}(\mathrm{f})$, 824 (h) and 825 (a) (1947). The contents of 49 U.S.C. $\$ \$ 481$ (e) (1948), of the Civil Aeronautics Act, lends further weight to an exclusive federal position. This section pertains to certificates of public convenience and necessity for carriers operating when the Act became effective, by a "grandfather clause" provision. Paragraph (2) reads: "If paragraph (1) of this subsection does not authorize the issuance of a certificate authorizing the transportation of mail between each of the points ... the Board shall, notwithstanding any other provision of this chapter, issue certificates authorizing the transportation of mail and all other classcs of traffic for which authorization is sought between such points, namely, ... (B) from Bismarck, North Dakota, to Minot, North Dakota; (C) from Detroit, Michigan, to Sault Sainte Marie, Michigan, via intermediate cities; (D) from Brownsville, Texas viā Corpus Christi, and Houston, to San Antonio, Texas; ...." Thus federal regulation of wholly intrastate routes is specifically provided for.

The rallroads are cited as the model upon which the airhine picture should be patterned, see Petitioner's Briefs, United Airlines Briefs, No. SF 18426, Calif. Sup. Ct. It was in regard to ICC power over railroads that the mitial federal-state battles were fought, and a measure of state power excluded from federal control. The exclusionary provision now in the Interstate Commerce Act, 49 U.S.C. 1(2) (1948), states: "Transportation subject to regulation-the provisions of this chapter shall also apply to such transportation of passengers and property ... but only insofar as such transportation . . . takes place within the United Statcs, but shall not apply-(a) to the transportation of passengers or property ... wholly within one state ...." 


\section{The Carrier Solution of CAB Counsel}

The General Counsel of the Civil Aeronautics Board analyzes the problem in terms of whether the purpose of the carrier is to serve intrastate or interstate traffic. ${ }^{43}$ This approach would free some wholly intrastate carriers from federal economic control, but not other carriers serving traffic primarily interstate in nature. As a working rule of thumb, this test may be as practical as any. At least, it retains great discretion for the CAB to act or not, if and when it sees fit. However, this analysis has not yet received judicial sanction and may be accepted only on a tentative basis. ${ }^{44}$

\section{The Route Solution of the Catalina-Mainland Case}

The opportunity for a forward-looking judicial analysis was presented in the Catalina-Mainland case. ${ }^{45}$ Umited there argued that the federal statute preempted the field of air commerce and transportation, and also that the portions of the California Public Utilities Act authorizing PUC action violated the federal constitution. The Court refused to touch these issues, as unnecessary to a disposition of the case, because of the availability of other adequate grounds. ${ }^{46}$ The Court stated:

"The Civil Aeronautics Act of 1938 defines interstate air transportation to inean 'The carriage by aircraft of persons or property ... between places in the same state of the United States through the air space over any place outside thereof.'

"The record here shows, by stipulation, that there is a distance of about 30 miles between the shoreline of the United States and the Santa Catalima Island. We have no difficulty in finding and so find, that a substantial portion of these 30 miles lies over the high seas and is not within the State of California. Hence it follows that air transportation through the air space thereover is over a place outside of the State of California.

"The Congress, by the statute, assuned jurisdiction over this area. This it had power to do. In this field, it has supremacy. Since the Congress

\footnotetext{
${ }^{43}$ Supra note 33.
}

44 Professor Noel T. Dowling suggests a topical approach to each particular field of transportation, Dowling, Cases on Constitutional Law 654 (3d ed. 1950). This approach would provide no help on the topic of air transportation, for the legislative history is so meager. See SEN. REP. No. 1661, 75th Cong., 3rd Sess. (1938) ; H.R. Rep. No. 2254, 75th Cong., 3rd Sess. (1938) ; H.R. ReP. No. 2635, 75th Cong., 3rd Sess. (1938); 83 Cong. Rec. 6401, 6626, 6766, $7064,8843,8961$ (1938). This history shows the purpose to be reorganization and unification of the federal agencies responsible for regulation of civil aviation. No thought was given to state regulation, the exclusiveness of federal control apparently was tacitly assumed. The reason for the distinction in the definitions of "air commerce" and "air transportation" is not revealed.

45 Umited Air Lines v. P.U.C., supra note 24.

$40 \mathrm{Id}$. at 15 , footnote 1: "The Supreme Court has made the frequent admomition that federal courts should refrain from invalidating statutes on constitutional grounds when there are other adequate grounds for decision: Hurd v. Hodge, 334 U.S. 24, 30 (1948); Rescue Army v. Municipal Court, 331 U.S. 549, 569 (1947); Arkansas Fuel Co. v. State of Louisiana ex rol. Muslow, 304 U.S. 197, 202 (1938); Baker v. Grice, 169 U.S. 284, 292 (1898). See Morgan v. U.S., 107 F. Supp. 501, 504 (W.D. Ky. 1952). 
had the power to assert federal jurisdiction, the plain language of the statute compels the conclusion that the Public Utilities Commission of the State of Cahifornia has no jurisdiction to regulate im any manner the transportation activities of the plaintiff over the route in question."

The inquiry here is whether the route is subject to federal regulation. By implication, any new carrier on the route would be required to possess a certificate under the economic regulations of the Civil Aeronautics Act. Applying this test to the San Francisco-Los Angeles route, which was flown only by federally certificated carriers before Cal-Central and Pacific Southwest entered the picture, should newcomers by required to possess a federal certificate? Since no flight over the "high seas" is involved is the route to be entirely free from federal economic regulation? The Court that decided the Catalina-Mainland case-again reading the statute narrowlywould apparently so hold, because no flight through the air space outside of California is-involved. Therefore, Cal-Central and Pacific Southwest are exempt from federal regulation. But what national or local interest justifies such distinction?

A more difficult question is involved over the Los Angeles-San Diego route. Pacific Southwest conducts regularly scheduled flight over this route, and without the aid of a federal certificate of convenience and necessity. The federally-established Civil Airway ventures out over the Pacific, in places farther than three miles from the low-tide mark. Does this involve a flight over the "high seas"? CAB has not yet required Pacific Southwest to have a certificate to fly this route, but the Catalina-Mainland court would apparently hold the certificate requisite to regular scheduled operations. It is submitted that the distinction between the two routes is without justifiable substance.

The soundness of the District Court's finding, without discussion or evidence of consideration of the ramifications, that the 30 miles of salt water constitutes the high seas is questionable. The case turns upon this point. A line drawn between Point Conception, Northwest of Santa Barbara, and Point Lonia, outside San Diego, passes southwesterly and to the seaward of Santa Catalina. ${ }^{47}$ For purposes of air commerce, is the water between these two headlands the high seas? Precedents and commentators on maritime law offer no usable answer. ${ }^{48}$ Does a flight between Key West

47 Approximately three miles. .

48 People v. Stralla, 14 Cal. 2d 617, 96 P.2d 941 (1939) ; U.S. v. Monstad, 134 F.2d 986 (9th Cir. 1943); Skiriotes v. Florida, 313 U.S. 69 (1941); The Abby, 1 Fed. Cas. No. 14 (C.C. Mass. 1818) ; Waring v. Clarke, 5 Howe 441 (1847) ; U.S. v. Rodgers, 150 U.S. 249 (1893) ; U.S. v. Utah, 283 U.S. 64 (1931) ; Bigelow v. Nickerson, 70 Fed. 113 (7th Cir. 1895); American Peanut Co. v. Merchants \& M.T. Co., 1 U.S. Ship. Bd. 90 (1930); Re Thames River Line, 1 U.S. Ship. Bd. 217 (1931), but cf. The J. Duffy, 14 F.2d 426 (Conn. 1926); The Yulu, 71 F.2d 635 (5th Cir. 1934); Benedict, The Law of AMarican Admiratty § 36 (6th ed. 1940). 
and along the Florida Keys to Miami travel through air space over any place outside of Florida? How about the direct route from Key West to Tampa; Cape Cod to Boston; Mamstique on the upper peninsula to Traverse City, Michigan; Toledo to Ashtabula, Ohio; Galveston to Brownsville, Texas; Rye, along the length of Long Island Sound to Greenport, New York; ${ }^{49}$ Wendover to Salt Lake City, Utah? Either these examples are questions of degree requiring an enterprising air carrier to risk its money upon the hope that its counsel correctly guessed which government is the controlling one, or else there is room for an interpretation of the Civil Aeronautics Act that these routes-between two points in the same state-are not over political territory outside the states, and that the Long BeachAvalon route likewise is wholly through the airspace over California.

In the Catalina-Mainland decision, the court felt constrained to call the area over which the airspace existed as something outside the state's political boundary. It chose the "high seas." In so doing, it did not analyze the meaning and social purpose of the concepts involved in the use of that term. It ignored the fact that the concepts belong to maritime law, and are entirely foreign to aviation law. The concepts are not included in the Civil Aeronautics Act. The term has no established meaning in air law. What purpose does the introduction of this term serve to air commerce? For what purposes may this term serve as a tool in the development of air commerce? The opimion is devoid of any clue to the answers to those questions.

By the introduction of the concept of the "high seas" into the case, the court ignored some obvious facts. Catalina is part of the political jurisdiction of California, and lies in Los Angeles County. ${ }^{50}$ The state has jurisdiction over the intervening waters for some purposes, while the federal governinent does, for others. ${ }^{51}$ Economic ties are entirely with the mainland area of Los Angeles. For the purposes of air commerce, is this an instance where the national interest is paramount because of the possible impact of state regulation upon interstate or foreign commerce?

The Court could easily have enjoined the PUC by finding a conflict between federal and state regulation of the carrier. In place of an analysis in terms of routes, an analysis based on paramount federal regulation would be entirely adequate. Such an analysis would have freed the carrier from dual regulation, but would have left the wholly intrastate carrier free to ply the route if the economic rewards were adequate. It would have avoided the anomaly of an extraneous concept determining the regulatory agency, and would have placed the emphasis where it properly belongs-

$49 \mathrm{Re}$ Thames River Line, supra note 48.

50 See Sec. 6, Los Angeles County Ordinance No. 5791.

51 Compare Wilmington Co. v. Railroad Commission, 166 Cal. 741, 137 Pac. 1153 (1913) and U.S. v. California, 332 U.S. 19 (1947). 
on whether national or local interest is paramount im a particular fact situation. As a contribution to aeronautical jurisprudence the opinion adds an extraneous concept to an already confused picture; it fails to evaluate the impact of the concept upon related situations; and, it fails to appreciate the inherent weakness of its choice of the operative fact upon which to base jurisdiction.

As a commentary upon the Civil Aeronautics Act, the decision clearly shows the need for modernization of the law and conplete review of the problem of regulation of air carriers. The Act served a valuable purpose for nuany years, but a new era is at hand and a complete and comprehensive review of all phases of economic regulation of air carriers is in order.

CAIIFORNIA CONSTITUTION, STATUTES AND DECISIONS

\section{The Law Review Controversy}

The first recorded discussion upon the question of PUC power over. intrastate air carriers under state law is contained in two articles in the California Law Review. The initial article ${ }^{52}$ took the position that the commission had no authority over air carriers, for the legislature had enacted no statute specifically granting jurisdiction under Section 23 of the California Constitution, Article XII, and Section 22 of Article XII was inapplicable because in Raitroad Commission v. Market Street Railway Com$p a n y^{53}$ the California Supreme Court held the section should be construed contemporaneously, and not anticipatorily-that is, that only types of carriers in existence at the time the provision was adopted were covered, not all carriers fitting into the general terms of the section.

The rebuttal article favoring PUC power ${ }^{54}$ was written by the Commission's chief counsel. It distinguished the original grant of power over rates and charges for common carriers contained in Section 22 from the legislative power to extend commission jurisdiction over public utilities under Section 23, and argued that the Market Street case was not in point, as the problem was controlled by the later case of Western Ass' $n$ of Short Lines Railroads v. Railroad Commission. ${ }^{55}$ The Short Lines decision required the Commission to assume jurisdiction over intercity but wholly intrastate motor freight and bus carriers under Section 22, whereas the earlier Market Street case prevented the Conmission from asserting similar jurisdiction over an entirely intracity street railway systen. The Short

\footnotetext{
52 Wolcott, Does the Jurisdiction of the California Railroad Commission Extend to Air Transportation?, 33 CALIF. L. Rev. 114 (1945).

53132 Cal. 677, 64 Pac. 1065 (1901).

54 McKeage, The California Railroad Commission Has Jurisdiction Over Intrastate Rates and Charges of Air Lines, 33 Carm. L. Rev. 298 (1945).

55173 Cal. 802, 162 Pac. 391 (1916).
} 
Lines case was offered by counsel to establish the principle that Section 22 is self-executing and is not to be construed contemporaneously. Therefore, Section 22 grants jurisdiction over common carriers by air.

\section{The Constitution and the Supreme Court Cases}

In the Cal-Central decision, the PUC basically followed its counsel's approach that Section 22 covers more than the types of public utilities in existence in 1911, when the section was adopted. The Commission rested its claim to jurisdiction upon Sections 20 and 22. These sections cover air carriers operating in California if the broad interpretation is adopted.

Section 20 reads:

"No railroad or other transportation company shall raise any rate of charge for the transportation of freight or passengers or any charge connected therewith or incidental thereto, under any circumstances whatsoever, except upon a showing before the . . . commission . . . that such increase is justified."

Section 22 states:

"[The] Commission shall have the power to establish rates of charges for the transportation companies, and no railroad or other transportation company shall charge or demand or collect or receive a greater or less or different compensation for such transportation of passengers or freight, or for any service in connection therewith .... No provision in this Constitution shall be construed as a limitation on the authority of the legislature to confer upon the ... commission additional powers of the same kind or different from those conferred herem which are not inconsistent ... and the authority of the legislature to confer such additional powers is expressly declared to be plenary and unlimited by ... this Constitution."

Following the early article, the carriers argued the PUC has no jurisdiction over "common carriers" unless the legislature has specifically granted such power by statute. "Common carriers" is defined in Section 17, which states:

"All railroad, canal and other transportation companies are declared to be common carriers and subject to legislative control ...."

The relevant portion of Section 23 is:

"... every common carrier, is hereby declared to be a public utility subject to such control and regulation by the ... (PUC) as may be provided by the legislature, ... (PUC) shall have and exercise such power and jurisdiction to supervise and regulate public utilities ... and to fix the rates to be charged ... as shall be conferred by the legislature."

In Railroad Commission v. Market Street Railway Company, a petition for writ of mandate, to force a San Francisco streetcar company to submit to Commission jurisdiction under the broad interpretation of Sec- 
tion 22, was denied. The Commission argued that the section was a direct grant of jurisdiction over all "railroad and other transportation companies" to establish rates and charges for carriage of passengers and freight. The Court limited the meaning of the section to cover only those railroads and transportation companies that the draftsmen of the section were concerned with in 1911. This subjective legislative intent did not apply to street railway companies operating wholly within the limits of a municipality. ${ }^{56}$

"In order to correctly determine this question, we must look to the words used, the context, the object in view and the evils that were intended to be remedied. In this manner we should, if possible, arrive at the intention of the convention in using the words, and give them the same meaning and effect as was intended by the people, through their representatives, in framing the constitution."

The court took judicial notice of the legislative intent to control big, statewide railroads which were then abusing their economic size and power, and not local streetcar systems. To support its view, the court referred to a similar legislative construction of the section made soon after the constitution was adopted: ${ }^{57}$

"While the interpretation given to the act by the legislature is not controlling ... yet, where it is doubtful, the courts may, very properly, look to the contemporaneous interpretation given such provision, either by the legislature or the courts. Particularly is this the case where the interpretation has been upon the statute books unchallenged for 20 years."

A lone but strong dissent by Mr. Justice Temple argued that the construction given by the majority was an improper restriction upon the constitutional provision..$^{58}$

"That the phrase, 'railroad and other transportation companies', does include street-railroads, in its natural and most obvious sense, and also by common usage of words, is not and cannot be denied .... . Street railroads are not specifically mentioned, because included in the general language. If it were not intended to include them, they should have been mentioned, as thy were in the act of $1880 \ldots$ Written laws will lose their usefulness if unequivocal terms can be limited to that courts think ought to have been included .... Contemporaneous construction can have no weight whatever where there is no doubt or ambiguity in the terms used, and none arises by implication from the context."

In Western Ass'n of Short Line Railroads v. Hackett et al. ${ }^{\text {s0 }}$ the Commission applied what it thought was the Market Street doctrine and refused

56 Supra note 53 at 678, 64 Pac. 1065.

57 Supra note 53 at 680,64 Pac. 1066. However, the U.S. Supreme Court was not so solicitous for antiquity in Wimters v. New York, 333 U.S. 507 (1948).

58 Supra note 53 at 685, 64 Pac. 1068.

698 Cal. R.R. Comm. 220 (1915). 
to prescribe rates and charges over intercity motor freight carriers and bus lines. These carriers were not within the subjective legislative intent of the enactors of Section 22; therefore, the Commission held that specific legislative authority was required before the Commission's jurisdiction would extend to such carriers. However, in Western Ass'n of Short Line Railroads v. Railroad Commission, ${ }^{\text {b0 }}$ the Supreme Court again disagreed with the Commission, and by writ of mandate directed the Commission to assume jurisdiction over motor freight and auto bus carriers and establish rates and charges upon intercity routes wholly within the state. The Mar$k e t$ Street case was distinguished and severely limited: ${ }^{\text {11 }}$

"All, therefore, that was actually decided in the Market Street case was that the Market Street Railway and other street railways of its character were not embraced within the meaning of the phrase 'other transportation companies,' as employed in the constitution. The most that was inferentially declared . . . was that other transportation companies operating wholly within the limits of a municipality were not within the contemplation of the constitution. Further than this the decision did not go, and further than this it should not be carried."

Justice Temple's earlier dissent was inferentially approved when the construction he advocated was adopted: ${ }^{22}$

"As little will it be questioned but that if the quoted language of Section 22 stood alone as a subject of construction it would be unhesitatingly held, in the present day, as it is held in construing similar language in other states, that it conferred upon the railroad commission regulatory powers over all transportation companies, therein including transportation companies, of the classes under consideration .... Did the constitution in the language quoted exclude by necessary or even fair construction control over transportation companies of the character here presented? Assuredly nothing in the language of the grant excludes them, and no legitunate construction upon the so oft quoted demands their exclusion. It must be and therefore is held that the constitution has granted regulatory powers over such corporations to the railroad commission by virtue of Section 22."

While distinguishable on their respective facts and reconcilable in their holdings, the decision in the Short Lines case is essentially inconsistent with the earker Market Street decision, and, if the later decision is to be followed the constitutional jurisdiction of the Public Utilities Commission to regulate rates and charges of railroad and other transportation companies under Section 22 is limited only in that it does not extend to transportation comparies operating wholly within the limits of a municipality. ${ }^{63}$ Under Section 23, the legislature may enlarge PUC jurisdiction to cover

\footnotetext{
co Supra note 55.

61 Supra note 55 at 808,162 Pac. 393.

62 Supra note 55 at 805,162 Pac. 392.

03 R.R. Comm. v. Market Street Railway Co., supra note 53.
} 
more than rates and charges. However, mumicipally-owned public utilities may not be regulated under such legislation, ${ }^{64}$ and additional authority must be "cognate and germane" to the purposes of the commission's powers. ${ }^{65}$ Fare increases must be approved by the Commission before becoming effective. ${ }^{6}$ Reductions may be made at carrier discretion, subject to later PUC disapproval if found to be unreasonable. ${ }^{67}$

A curious throwback is In re Martinez. ${ }^{68}$ Martinez was convicted of violating Sacramento's municipal taxicab ordinance. On petition for habeas corpus, he argued that Section 23 provides that "public utility" includes "common carrier," and "common carrier" as defined by Civil Code Section 2168 includes taxicabs; therefore, since Section 23 grants the PUC exclusive jurisdiction over public utilities, the PUC and not the city had exclusive jurisdiction to regulate taxicabs and his conviction under the municipal ordinance was improper. This argument was rejected because taxicabs were not enumerated in the Public Utilities Act. In so holding, the Supreme Court made statements regarding powers exercised pursuant to Section 23 legislation that appear to apply to powers exercisable pursuant to the direct grants of Section 22. Chief Justice Gibson quoted from Section 23, as follows:

"... the public utilities therein defined (including common carriers) shall be 'subject to sucl control and regulation by the Railroad Commission as may be provided by the Legislature.' The section further provides that 'The Railroad Commission shall have and exercise such pozer and jurisdiction to supervise and regulate public utilities ... and to fix the rates to be charged for ... services rendered by public utilities as shall be conferred upon it by the Legislature ....' (Italics ours.)

"The italicized language is clear in its declaration that only sucl of the utilities therein designated, including common carriers operating within a municipality, may be regulated by the Railroad Commission as are made subject to such regulation by legislative enactment. In other words, while a taxicab is a common carrier (code sec. supra; Bezera v. Associated Oil Co., 117 Cal. App. 139, 143 [3 P.2d 622]; 45 A.L.R. 300) and section 23 of article XII of the Constitution declares every common carrier to be a

64 Civic Center Ass'n. v. R.R. Comm., 175 Cal. 441, 445, 166 Pac. 351, 353 (1917); San Bernardino v. R.R. Comm., 190 Cal. 562, 213 Pac. 980 (1923).

65 City of Pasadena v. R.R. Comm., 183 Cal. 526, 192 Pac. 25 (1920); E.B.M.U.D. v. R.R. Comm., 194 Cal. 603, 229 Pac. 949 (1924). The origin of the "cognate and germane" limitation may be traced to dicta in Pac. Tel. \& Tel. Co. v. Eshleman, 166 Cal. 640, 137 Pac. 1119 (1913).

66 CaI. Const. Art. XII, § 20.

67 Scott, Magner \& Miller v. Western Pacific Railway Co., 2 Cal. R.R. Comm. 626 (1913), discusses the history of Section 22, showing that prior to 1911 the commission lad the duty to prescribe rates, conclusively presumed just and reasonable; after the 1911 amendment carriers file their own rates and are liable for reparation if not just and reasonable under legislation enacted pursuant to Section 23 of Article XII.

68 22 Cal. 2d 259, 138 P.2d 10 (1943). 
public utility, the constitutional section further expressly declares that the public utilities therein designated shall be subject to sucli control and regulation by the Railroad Commission 'as may be provided by the Legislature.' To determme whether taxicabs and the rates thereof are subject to the jurisdiction of the Railroad Commission we must therefore look to the statutes enacted by the Legislature."

It is submitted this is too broad. As it applies to Section 23, it may be correct if the Market Street interpretative technique is followed; however, particular carriers may be subject to PUC jurisdiction without aid of Section 23 legislation, or else Section 22 is rendered nugatory. It is doubted that the Chief Justice intended to read Section 22 jurisdiction out of the Constitution, and especially so without mention of the Short Lines decision. Further, this statement does not take into consideration the sentence in Section 23 that states, "Nothing in this section shall be construed as a limition upon any power conferred upon the ... Commission by any provision of this Constitution now existing or adopted concurrently herewith," and the provisions of Section 22 directly granting jurisdiction to the commission over railroads and other transportation companies.

PUC was not attempting to regulate taxicabs in Sacramento and adoption of Martinez's line of reasoning would have required repudiation of local taxicab regulation. The argument made by the Court was essentially a negative one-PUC has no jurisdiction, for the Act does not enumerate taxicabs, and therefore the Act is not a reason to overturn an otherwise valid conviction. The issue was not a choice between regulative bodies, such as if the City of Sacramento and the PUC were both claiming exclusive jurisdiction, but whether municipalities could regulate taxicabs to the extent necessary to sustain the conviction. There were strong local considerations present in upholding the conviction, and no competing state interest in setting it aside. The Court answered Martinez's claim and did not consider the implications of its statements as they appear to apply to the right of the Public Utilities Commission to regulate other types of carriers.

- Under Sections 6, 8 and 11 of Article XI, California Constitution, as developed in Grier v. Ferrant, ${ }^{69}$ taxicab regulation is purely a municipal affair and conviction should have been sustained upon that basis with the result that the unfortunate dicta in the Martinez opinion could have been avoided. It is submitted that the Martinez dictum is an aberration in the picture of public utility regulation and should be judicially repudiated, and the sooner the better, for it only causes confusion and complication of an already confused and complicated picture.

\section{The Cal-Central Decision}

While the foregoing analysis is in terms that Section 22 is a self-executing grant of jurisdiction to the Commission and that Section 23 authorizes

6062 Cal. App. 2d 306, 144 P.2d 631 (1944). 
the legislature to grant additional powers as it sees fit and necessary, the PUC became unnecessarily tangled in a web of its own making when it rendered its Cal-Central decision by invoking Section 22 for its grant of jurisdiction, and legislation authorized by Section 23 for punitive purposes, thus leaving the question of the extent of its powers over air carriers in a state of greater uncertainty than before. It was not satisfied to accept the power recognized by the Supreme Court as belonging to it by virtue of the Constitution, but reached out for more power, to apply a penalty for failure to comply with an order impossible on its face-not to charge higher fares from March 1 to the date of the order, April 24. In so doing, it may have set the law regarding its constitutional powers back forty years.

The carriers argued that the Commission had no jurisdiction over them because of the absence of specific legislation enacted pursuant to Section 23, and that Section 22, under the Market Street decision, does not extend to types of carriers not in existence in 1911. The PUC rejected this argument and found that it did possess sufficient jurisdiction under Sections 20 and 22, applying the theory of the Short Lines case. Thus establishing its competence, the PUC proceeded to find the higher charges to be reasonable, and ordered them into effect on May 9. Since Cal-Central, United and Western were already charging the higher fares, rebates were ordered "wherever possible" to persons overcharged before May 9.

In rejecting the carriers' jurisdictional argument, the PUC denied that it needed Section 23 legislation to act, and distinguished the Section as a source of power, but still relied upon the penalty provisions of the Public Utilities Act, a statute enacted by the legislature pursuant to Section 23. The opinion states:

"The grant of jurisdiction to the commission over intrastate rates of air carriers is found in Sections 20 and 22 of Article XII of the Constitution, Section 23 can claim no priority over Sections 20 and 22 of said Article unless the former provision is more specific than the latter. As a matter of fact the latter is more specific than the former with respect to the regulation of rates of 'other transportation companies.' Should there be any possible ground for doubt on this point, the provisions of Section 23 are conclusive against the contention of respondents. Said Section 23 further provides, in part, as follows: ' . . Nothing in this section shall be construed as a limitation upon any power conferred upon the ... (PUC) by any provision of this Constitution now existing or adopted concurrently herewith.'"

$$
\text { * * * * * }
$$

"The order which follows will authorize publication and maintenance of the $\$ 11.70$ fare for the future. These companies are hereby placed on notice that they are and will hereafter be deemed to be 'transportation companies' within the meaning of the Constitution of the State of California, and that they are subject to the prohibitions and requirements of said Con- 
stitution. We also call the attention of these companies to Section 76(a) of the Public Utilities Act, which provides:

" Any public utility which violates or fails to comply with any provision of the Constitution of this state or of this Act, or which fails, omits or neglects to obey, observe or comply with any order, decision, decree, rule, directive, demand, requirement, or any part or provision thereof, of the Commission, in a case in which a penalty has not hereinbefore been provided for such utility, is subject to a penalty of not less than five hundred dollars nor more than two thousand dollars for each and every offense." "

If the purpose of the Cal-Central decision was to establish PUC powers to regulate rates and charges of air carriers operating over intrastate routes, a more clear-cut precedent would have been created by avoiding reliance upon any legislation enacted pursuant to Section 23. Simple reliance upon Sections 20 and 22 would have sufficed. If the Commission was not seeking litigation of the jurisdictional question the reason for the penalty must have been to back up an order ineffectual on its face-requiring rebates "wherever possible"-and impossible of performance in that it prohibited action that had already occurred. An order of such insignificant impact hardly justifies confusing the jurisdictional issue. Has not the moth consumed itself in its quest for the flame?

\section{The Latest Decisions}

After the Cal-Central decision had survived the gamut of appeals through the courts, the PUC commenced actions to collect penalties from the carriers for not complying with the Commission's order upon the theory that Section 2107 of the Califorma Public Utilities Code authorized collection of penalties in such circumstances. United made its case upon interpretation of the section, arguing that the legislature did not intend to subject air transportation companies to PUC jurisdiction, for it has never expanded the definition of "public utilities" as used in the Public Utilities Code to cover other than the enumerated types of carriers, which enumeration does not include air carriers. Cal-Central and Western both challenged PUC jurisdiction over air carriers under the Califorma Constitution and the Public Utilities Code.

In People v. United Air Lines, ${ }^{70}$ the division of the District Court of Appeals sitting in San Francisco held that the Commission was without statutory authority to assess the penalty, but suggested by way of advice that a contempt action was proper. This decision is the first by a state court interpreting the Public Utilities Act (now Part 1, Div. 1 of the Public Utilities Code) as it may apply to common carriers by air. Judge Wood stated:

"The sole issue upon this appeal is whether or not this defendant by chargmg the increased rates mentioned, during the period March 1 to May 8,

${ }^{70}$ Supra note 22 at 457,258 P.2d at 68 . 
1951, incurred penalties which under certain circumstances the provisions of section 2107 of the Public Utilities Code by its terms imposes. That section declares that 'Any public utility which violates or fails to comply with any provision of the Constitution of this State or of this part [\$§2101 to 2113; the Public Utilities Code], or which fails or neglects to comply with any part or provision of any order, decision, decree, rule, direction, demand, or requirement of the commission, in a case in which a penalty has not otherwise been provided, is subject to a penalty of not less than five hundred dollars $(\$ 500)$ nor more than two thousand dollars $(\$ 2,000)$ for each offense.' (Emphasis added.)

"The key words in this section are 'public utility.' Unless defendant is a 'public utility,' as that term is used in section 2107, it cannot be subject to the penalty which that section imposes.

"For a definition, we turn to section 216 of the code. It states that "Public utility" mcludes every common carrier, toll bridge corporation, . . . [and a number of types of corporation other than transportation companies] ... where the service is performed for or the commodity delivered to the public or any portion thereof ....'

'Here the key words are 'common carrier,' defined in section 211 of the code as follows: "Common carrier" includes ... (specifying several types of carriers).

"In this definition of 'common carrier' there is no specific mention of common carrier by air. It is true that this enumeration of carriers is preceded by the word 'includes,' which ordinarily is used by way of illustration or enlargement, not by way of limitation. (Oil Workers Intl. Union v. Superior Court, 103 Cal. App. 2d 512, 570 [230 P.2d 71], and cases there cited.) Here, however, it appears that 'includes' is used as a word of limitation. The enumeration of several types of common carriers ... suggests an intention to include only the carriers specifically mentioned. The history of this section, which finds its prototype in subdivision (1) of section 2 of the Public Utilities Act of December 23, 1911, (Stats. 1911, Ex. Sess., ch. 14, p. 18, at pp. 19-20), compels such a conclusion."

The court then examined the history of the statute, and found that it included "other transportation companies" in the defimition of common carrier up until the revision of the Public Utilities Act in December 1911, after sections 20,21, 22 and 23 of Article XII of the Constitution were amended in October of that year. The revision of the Act did not define "transportation company" or use the term in any section thereof. This the court felt was of "prime significance" and indicated the legislative intent of excluding from PUC jurisdiction types of carriers not specifically covered.

"It would seem, therefore, that the absence of the term 'transportation company' from the code is no accident; that it is the result of an intentional act of exclusion. This fact, coupled with the specific enumeration of carriers in the statutory defimition of 'common carrier,' suggests that the Legislature, soon after the 1911 amendment of the Constitution, adopted the policy of not exercising its 'plenary' power over any new type of 'transportation company' (such as a stage lime, truck line, or air line) until that type 
of transportation shall have been in operation long enough for the Legislature to determine how much, if any, regulation and control over it should be given the commission in addition to that directly conferred by the Constitution."

The Short Lines decision was distinguished upon the grounds that it referred to constitutional and not statutory jurisdiction. The court referred to In re Martinez and appears to limit that decision to statutory jurisdiction, avoiding the broad language covering Section 22 constitutional jurisdiction.

The inference that the Commission possessed constitutional jurisdiction, but was without means of enforcing it, bothered the justices. As a palliative they suggested the Commission had another weapon in its arsenal that may suit its purposes better than penalties.

"We note in passing that section 2113 of the code, relating to contempt of the commission and its power to punish such a contempt, is broader in its application than section 2107. Section 2113 applies to every 'public utility, corporation, or person.' That nuy well include a common carrier by air to the extent that such a carrier, viewed as a 'transportation company,' may be subject to the jurisdiction which section 22 of Article XII of the Constitution confers upon the commission. Our attention has been called to no other provision of the Public Utilities Act portion of the code which directly or indirectly mentions common carriers by air."

If the issue presented is as narrow as the Court suggested, it is difficult to quarrel with the strict statutory interpretation used by the court. The opinion is incisive and logical in holding that air transportation companies are not "public utilities" under the definiton as used in the Act. Under the circumstances, the decision literally closes the proverbial barn door as nearly as possible. The carrier cannot be punished by way of penalty, but if it violates a Commission order again, it can be held in contempt. Maybe a spring-gun is a means of stopping the next horse thief, but how about the one that just got away?

Viewed in a broader perspective, is the historical analysis of legislative intent sound? The original text of Section 22 of Article XII contained all the substantive provisions relating to Commission powers, including levy of penalties and legislative authority to confer additional powers upon the Commissioners "as shall be necessary to enable them to perform the duties enjoined on thein ..." There was no grant of power to the legislature to expand commission jurisdiction. Section 23 merely outlined temporary railroad districts.

The 1911 revision of Sections 22 and 23 may be interpreted as splitting apart the substantive provisions contained in the original Section 22 and adding legislative authority to expand commission jurisdiction and powers

71 . 2 Mason, California Constitution 383 (1953). 
to cover other industries that constitute or are found by the legislature to constitute public utilities. Section 22 provided for continued existence of the Railroad Commission Act as it existed before the revision and the new Section 23 provided that nothing contained therein should limit the constitutional powers of the commission. There is nothing to suggest a reduction in commission powers over matters within its previous jurisdiction. The former Section 22 established maximum fines for violations of commission orders, which provision was removed from the revised Section 22 and not included in the new Section 23. However, the Railroad Commission Act referred to in the revised Section 22 contained provisions regarding fines similar to those removed from the Constitution. ${ }^{{ }^{2}}$

In view of the context of the 1911 revision to the Constitution, the constitutional provisions and legislative additions to commission powers may reasonably be construed as providing a unitary, integrated regulatory system, so that the supplementary powers enacted pursuant to Section 23 apply to violations of orders by any public utility-whether a railroad within the defimition of Section 22, a Trans-Mohave Burro Express, or an air transportation company which is a post-1911 event in the field of mass transportation and beyond the legislative intent only because of the inability of the legislators to see 40 years into the future. The court chose not to so construe the constitutional and statutory sections, in spite of what it admits is the general rule of construction, i.e., the word "includes" in a definition is ordinarily used by way of illustration or enlargement, not by way of limitation. If the legislature meant to limit the definition of "common carrier" as used in the Public Utilities Act, why did it not say so?

Also, Section 24 provides that "the Legislature shall pass all laws necessary for the enforcement of the provisions of this article (Art. XII)." In view of this explicit statement regarding the purpose of Public Utilities Code Section 2107, it would appear that the legislation that is enacted should be interpreted to render the constitutional provisions more effective, and not less so.

The Court showed nothing but grammatical analysis to support a conclusion of changed public policy as significant as its decision that an order made pursuant to constitutional sanction may be intentionally disregarded without penalty. Would not a comprehensive piece of legislation place the Commission and the carriers upon firmer ground and serve public policy well in regulating, or in leaving alone the carriers that now are serving the most heavily traveled air route in America?

The division of the District Court of Appeals that considered the actions against Cal-Central and Western Airlines reached a similar result with only

722 Mason, CaIffornia Constitution 381 (1953). 
a small variation of the theme. Cal-Central again challenged the Commission's jurisdiction and was met with a reply of res judicata. Justice Drapeau held, however, in People v. California Central Airlines, ${ }^{73}$ that the only issue that was foreclosed by the previous action was "the propriety of an increase in passenger fares," which issue was not before his court. He then disposed of the penalty issue the same as did the San Francisco division of the Court.

"Neither in the constitutional provisions nor in the enabling acts is any mention made of air transportation.

"In view of the precise particularity used in denoting the types of businesses sought to be regulated, the Legislature must be deemed to have intentionally excluded air transportation companies from operation of the Public Utilities Act. In other words, the jurisdiction of the commission extends only to such common carriers and public utilities as are specifically designated in the statute."

The court then proceeded to adopt the analysis of the early law review article regarding the significance of the Martinez case, concluding,

"By this decision the Supreme Court has reaffirmed the principle that the commission possesses no inherent power but only such jurisdiction as is specifically given to it.

"As a result, the commission has no jurisdiction over air transportation companies."

People v. Western Airlines, Inc. ${ }^{74}$ was decided the same day upon authority of People v. California Central Airlines.

This decision is subject to the same objections as People v. United Airlines. The significant difference is the broader ground upon which the decision is based. While the San Francisco court held only that the penalty provisions of the Public Utilities Act did not apply to air transportation companies, it appeared willing to recognize that some constitutional jurisdiction did exist. ${ }^{75}$ The Los Angeles court would recognize no jurisdiction in the absence of a statute. In so doing, the latter passed over the Short Lines case without comment and gave no effect to that decision, relying instead on the Martinez dictum. Now the Supreme Court will review these decisions and render an explanatory opinion. No situation was ever more ripe for review.

It is of interest that the conflict of federal and state jurisdictions was not seriously considered by Umited and Western in the state court proceedings. Counsel are fighting the battles one by one and saving their heavier artillery for later offensives by the Commission. As yet, PUC has not forced the federally certificated carriers to submit their standard service fares and

\footnotetext{
73 Supra note 22 at 686,258 P.2d at 579.

T4 Supra note 22.

76 118 A.C.A. $454,457,258$ P.2d 66, 67 (1953).
} 
charges, but only air coach fares, to an investigatory proceeding, even though both types of fares are within the PUC rate fixing powers, if either is. The reason for this discrimination by PUC has not been explained.

Section 22 also authorizes the Conumission to prescribe a uniforn system of accounts to be kept by all railroad and other transportation companies. However, no order has yet been made in this regard.

Any action in these two areas imposing different fares or additional administrative duties on the carriers would create a clear conflict with federal jurisdiction under the Civil Aeronautics Act. This fact did not deter the Commission from making its rebate order covering fares that are subject to federal regulation as are United and Western coach fares. Thus, fear of a federal conflict is not the basis of the Commission's omission. Why only a partial assumption of jurisdiction was made has not been explained. If the Commission comes out well in its present attack, perhaps the discrimination will be ended and standard service fare regulation will follow.

One additional case deserves comment. In Smith v. O'Donnell, ${ }^{76}$ the Supreme Court held that an air carrier making regular flights from an airport and carrying passengers for hire was a common carrier within the definition of Civil Code Section 2168 establishing the standard of care required for tort liability purposes. Civil Code Section 2168 provides:

"Everyone who offers to the public to carry persons, property, or messages, excepting only telegraphic messages, is a common carrier of whatever he thus offers to carry."

Is this not an expression of legislative intent that air transportation conpanies such as here considered are common carriers and within the meaning of the tern as used in the Public Utilities Act?

\section{Need for Comprehensive Review of State Law}

The history of expanding specific statutory authorization for public utility regulation in California is a source of much uncertainty. The Market Street interpretative technique, combined with the attempts of newly developing transportation systems to secure a particular and special legislative treatment of their operations, has resulted in a patchwork development of public utility regulation. Since only the enunierated or subjectively legislated against "evils" are covered by previous legislation, a new enactment has been made to take in each new "utility" that appeared. The result is that there is no generally acceptable legislative definition of common carriers or carriers subject to PUC control, but only random statements that a certain type of business operation is subject to or exempt from PUC

76215 Cal. 714, 12 P.2d 933 (1932). 
jurisdiction. Different and competing types of carriers are subject to different degrees of control. When the Public Utilities Commission assumed jurisdiction over air carriers in a direct manner, a new approach to public utility regulation was adopted, but has been bogged down by adverse judicial opinions. If there is room for state action in a balanced federal regulatory pattern, the need for a comprehensive Supreme Court review of the state constitutional and legislative provisions applying to air carriers is unmistakably clear.

The problems presented by the existing limitations which call for correction and clarification and for removal of judicially applied gloss on constitutional provisions are only commencing. Already urban area helicopter operations have been established in California. The Los Angeles Air Service now provides mail and passenger service between localities in the Los Angeles basin. The CAB is accepting applications for like service in the San Francisco-Oakland area.

As the present service in the Los Angeles area is wholly intrastate, the PUC may have the power to regulate the rates and charges for carriage of passengers and freight. PUC constitutional power is limited to rates and charges, and does not include service, schedules and certificates of public convenience and necessity, so that incomplete regulation of these carriers results. This is the case with the intrastate routes now being regulated.

The solution is not solely legislative; however, for the legislature can only add to commission powers. It cannot limit the constitutional grants. By judicial gloss the legislature can only enact statutes that are "cognate and germane" to the regulation and control of public utilities. ${ }^{77}$ The content of this latter himitation has never been defined. However, regulation of rates and services of a municipally-owned and operated public utility is not "cognate and germane." 78 Thus by analogy, if a municipality were to operate an air transportation system to surrounding communities, or over all the state, that system would, conceivably, be subject only to the regulations prescribed by the legislative body of the municipality. This might be a solution to the problems of municipal revenues, but hardly a contribution to development of a state-wide aerial transportation system by the traditional forces of free enterprise that have developed the existing high density air travel routes within the state.

Until the Supreme Court clears away the uncertainty regarding the degree and kind of regulation and competition to which air carriers can be subjected under the existing constitutional and statutory provisions, further development of additional routes providing cheap and convenient air transportation to the public will be seriously retarded.

77 Pasadena v. R.R. Comm., sabpra note 65.

78 Supra note 65. 


\section{CONCLUSION}

The existing jurisdictional confusion must be dispelled if further development of air travel within the state is to progress rapidly and in an orderly manner. There is substantial doubt whether, under the provisions of the Civil Aeronautics Act of 1938, there is room for any state agency to provide economic regulation of air carriers, be they engaged in interstate or wholly intrastate commerce. The Catalina-Mainland appeal presents to the Supreme Court of the United States the opportunity to resolve this question if that court desires to choose the broad basis of decision that the federal statute excludes the states. It is believed that Congress thought it was doing that very thing in 1938 and did not consider that any state action was necessary or appropriate, but it failed to express itself clearly in that regard. However, in the light of fifteen years of experience under the Act and development in the art of aviation a reconsideration of the Act by Congress is in order.

The state law may be clarified by a removal of the judicial gloss applied by the Market Street and Martinez cases and establishment of the full constitutional authority of the PUC to regulate all transportation companies. The California Supreme Court declined to clarify the law in the first instance presented to it of air carrier regulation. If it does not do so now, the remedy is a comprehensive legislative enactment for air carriers, or revision of the Public Utilities Code to redefine the regulatory structure regarding common carriers to include all common carriers.

Califorma has lead in the development of intrastate air commerce largely due to fortuitous circumstances. If it is to continue in the forefront it should encourage further development of the great potential by a farsighted and sympathetic governmental attitude or face an alternative of greater federal control, which may well result in disregard of legitimate local interests. Such disregard has occurred when the federal regulating body ignored state and community desires and the willingness of carriers to provide service to these needs. ${ }^{79}$ It is submitted that clarification of the federal statute is desirable, but that it should give an appropriate place to the states to fulfill this function, and the states, commencing in California, should demonstrate their ability to further encourage new developments and create a favorable environment by elimination of unnecessary regulation within a framework of gnarantees of service and safety to all.

${ }^{79}$ A classic example is the North Central case, 7 C.A.B. 639 (1946) discusscd in Starr, The Position of the States in Economic Control and Regulation of Air Commerce, $15 \mathrm{~J}$. ArR L. \& Comm. 127, 149 (1948). Recent examples in the far West are Western Air Lines v. C.A.B., 196 F.2d 933 (9th Cir. 1952) and Southwest Airways Co. v. C.A.B., 196 F.2d 937 (9th Cir. 1952). See also Dinu, State Aviation Officials-Some of Their Duties, Responsibilities, and Activities, 15 J. ATr L. \& Comar. 309, 314 (1947), discussing a Michigan problem where the upper Peninsula is separated from the rest of the state and the C.A.B. required air traffic to go through Chicago to reach Detroit. 